\title{
"What Is This, the Seventies?" Spectres of the Past (and the Future) in Recent Northern Irish Television
}

Television \& New Media

(C) The Author(s) 2020

Article reuse guidelines: sagepub.com/journals-permissions DOI: $10.1177 / 1527476420985826$ journals.sagepub.com/home/tvn

@SAGE

\section{Colin Coulter'}

\begin{abstract}
For all the gains made during its celebrated peace process, Northern Ireland remains haunted by a conflict that claimed more than 3,700 lives. One of the spaces in which the ghosts of the past manifest themselves is that of television drama. In this article, Mark Fisher's reading of "hauntology" provides the theoretical frame for an analysis of two recent TV series set in Northern Ireland: The Fall and Derry Girls. Although the programs could not be more different in both tone and content, they both illustrate sharply that the region remains, in John Hewitt's indelible phrase, a "ghost-haunted land." In particular, The Fall and Derry Girls reveal that Northern Ireland continues to be deeply troubled both by those who were lost during the conflict and by that which was lost in the transition to peace.
\end{abstract}

\section{Keywords}

Northern Ireland, hauntology, The Fall, Derry Girls, Mark Fisher, spectres

\section{Introduction}

The political accord struck on 10 April 1998 that brought to an end almost thirty years of political violence in Northern Ireland has been widely lauded as a model for other societies emerging from conflict (Coulter and Shirlow 2019). For all its undoubted attributes and achievements, an essential flaw in the Good Friday Agreement was the

\footnotetext{
'National University of Ireland, Maynooth, County Kildare, Ireland

Corresponding Author:

Colin Coulter, Department of Sociology, National University of Ireland, Maynooth, County Kildare, W23 F2K8, Ireland.

Email: colin.coulter@mu.ie
} 
absence of any mechanisms for addressing the complex afterlives of "the Troubles." While those who framed the political settlement acknowledged the multiple "tragedies" that punctuated the conflict, they were keen to consign such moments to "the past," an historical period evidently conceived as entirely discrete from that under construction in a society now intent on making "a fresh start."1 This attempted "cauterization" (Graham 2005, 658) of Northern Ireland's violent recent history has shaped public policy over the course of the peace process. Although there have been several public inquiries into some of the major atrocities during the Troubles, there has never been a more comprehensive "truth and reconciliation" strategy. Furthermore, it would take until 2014 for the local parties to agree, finally, on a pension scheme for victims of violence which, entirely predictably, has yet to be implemented. In the absence of any coherent strategy for dealing with "legacy issues" associated with the conflict, it was always likely that the ghosts of Northern Ireland's turbulent recent past would return to haunt the region. One of the spaces in which these spectres of the Troubles have begun to appear in recent years is in dramas scripted for both the big and small screen. ${ }^{2}$ This article examines the latter medium, providing a close reading of two prominent contemporary television series - The Fall (2013-2016) and Derry Girls (2018-present) - which illustrate that for all the progress Northern Ireland has made over recent years, it remains, in John Hewitt's indelible phrase, a "ghost-haunted land" (McKay 2008, 11).

\section{Housetraining History}

In a Northern Irish context, a great deal more scholarly attention has been paid to cinema than to television. Writers such as Hill (2006), Barton (2019), and McLaughlin and Baker (2010) have noted that the advent of the peace process heralded a sea change in how Northern Ireland has been represented on the big screen. Those paramilitaries who were the principal protagonists in movies shot during the Troubles era have become ever less prominent and are now often depicted less as objects of fear than as figures of fun. As the preoccupation with the "men of violence" has receded, script writers have come to focus more on "ordinary people" (McLaughlin and Baker, 2010: 72,83 ) assumed to have little time for politics and to be rather more concerned with the quotidian domestic concerns of making a living, starting a family, salvaging a marriage from serial infidelity and so on. ${ }^{3}$ That turn toward the private proves emblematic of a wider public ambition to leave the past behind signified in the portrayal of the regional capital as newly dynamic and cosmopolitan. Once routinely depicted as a "pariah city" (McLoone, 2008: 52) Belfast has more recently been recast as a "commerce-driven city of glass" (Long, 2017: 31).

The trends that scholars discerned in the movies released in the early years of the peace process are also clearly legible in many of the fictional dramas for television set in, or dealing with, Northern Ireland that have appeared in the last decade. In 6Degrees (2012-2015), for instance, we follow a half dozen students through their undergraduate careers in a fictional Belfast university. The flatmates are shown occasionally in academic settings but are more often cast as workers and consumers in a night-time 
economy indistinguishable from that of most other late capitalist cities. While the dialogue in all three seasons plays heavily on the local accent and idiom for comic effect, there are notably few gestures to the historic violence or contemporary divisions that scar Belfast. When reference is made to the brutal paramilitary disciplinary technique of "kneecapping," for instance, it is made all the more incongruous by coming from Sheila, the elderly wealthy eccentric neighbor who becomes an unlikely confidante to the headstrong student Eva.

The political fault-lines that still run through Belfast are equally understated in another recent television drama set in the city. In the serialization of the stage play My Left Nut (2020), 15-year-old Mick fears that his suddenly swollen testicle may be cancerous. Among his group of close friends is Tommy, a figure taunted with claims that his father is in the IRA, the organization designated through the slang term "the "RA." Mick and his friends rehearse this allegation in the full knowledge that it is preposterous and in doing so implicitly mark the distance between the version of Belfast in which they are growing up and a previous rendition of the city that was mired in sectarian violence. This sense of dissociation is underlined in the final episode when it becomes clear that the passing references to paramilitarism have been made solely to set up one of the program's better punchlines. When it is discovered that Tommy's father hails in fact from the Protestant community, his friend Conor delivers the memorable quip: "Jesus, they'll let anyone into the 'RA these days."

The Troubles are also referenced with seemingly playful intent in a further recent television series, London Irish (2013), focussing on the lives of four young people from Northern Ireland who relocate to the English capital. In Lisa McGee's ill-starred sitcom - canceled after a single season following a hostile reception from the critics and public alike - the four main characters appear driven by concerns akin to those of their peers across the western world: precarious work, unstable personal relationships, recreational vices, and so forth. When very occasional references are made to the political specificities of Northern Ireland past and present these seem out of place, inserted solely to set up what are intended as comedic moments such as when a barroom discussion of the faded menace that a Belfast accent now holds in London leads Bronagh to make the predictable observation: "we're not the terrorists anymore. There's new terrorists. Better looking terrorists."

The political violence once closely associated with Northern Ireland appears, therefore, to have become increasingly marginal to its representation in television fiction. Indeed, there are some recent programs set in the region that have chosen to make no reference to its notorious sectarian divisions whatsoever. The three-part series Come Home (2018), about the struggles of a woman in Belfast to reconnect with the family she left suddenly and recently, represents a case in point. The gradual erasure of the political that has occurred in television concerned with Northern Ireland has eventually led to a certain ironic reversal. When the Troubles were at their height, security concerns meant that movies and tv programs set in the six counties often had to be filmed elsewhere. In the era of the peace process, however, Northern Irish locations have come to stand in for a range of other places, both real and fictional: Dublin in the dark three-part drama Paula (2017); an unspecified English city in the police 
procedural Line of Duty (2012-present); and, most famously, the mythical land of Westeros in Game of Thrones (2011-2019). ${ }^{4}$

The moving images that have documented Northern Ireland in the post-conflict era have in the main, therefore, sought to efface the events of the Troubles. At the same time, however, a further, countervailing trend is clearly discernible. The last decade or so has seen the appearance of dramas on both the big and the small screen that have sought to summon the ghosts of the region's violent past and to commemorate thoseand also that - lost in the transition to peace. This return toward a more mournful representation of the region seems to begin with the release of the acclaimed - and assailed - movie Hunger in 2008 and has found form in a sequence of films released since: Shadow Dancer (2012), '71 (2014), The Truth Commissioner (2016), The Dig (2018). While that change in tone is rather more clearly pronounced in the world of cinema, there are also certain examples of it in the realm of television, two of which will be examined here. These programs issue a critical reminder not to forget the ghosts of Northern Ireland's recent traumatic history as well as an injunction to acknowledge that even now Northern Ireland remains in a perilous state that might be deemed "hauntological."

\section{Learning to Live With Ghosts}

Derived originally from the work of Nicholas Abraham and Maria Torok (1978), the concept of "hauntology" is now more closely associated with Jacques Derrida's examination of the cultural world in the immediate aftermath of the end of the Cold War. The demise of the Communist project, Derrida suggests, has created a sense of loss reflected in a widespread mood of mournfulness. The spectres that remain from the dream of a genuinely egalitarian future are unlikely to disappear anytime soon. Living at the "end of history," Derrida (1994, xvii, xviii) observes, requires us to "learn to live with ghosts." One of the most engaging attempts to explore the "hauntology" that defines the modern world appears in the writings of the late cultural theorist Mark Fisher. In his collection of essays Ghosts of My Life, Fisher (2014) observes that the triumph of the neoliberal project signaled the demise of other, more progressive visions of the future. This closing down of ideological space-what Franco "Bifo" Berardi terms "the slow cancellation of the future"-has ensured that beneath the glossy surfaces of late capitalism there is a pervasive mood of "melancholia" (Ibid., 6). The term is employed here in a manner akin to Sigmund Freud, denoting a mode of grieving in which the bereaved refuses to relinquish the lost love object, a refusal that gives rise to certain pathologies. One of these disorders, Fisher suggests, expresses itself in the pervasive and debilitating nostalgia of the contemporary culture industries in general and popular music in particular. While the calling card of pop was once its facility for "future shock," it now seems haunted by its own past, constantly re-treading and re-issuing the songs and styles of a previous golden age.

Fisher is suitably withering in his depiction of the "extraordinary accommodation toward the past" (Ibid., 9) that defines mainstream popular culture in the early twenty-first century. He does, however, discern the existence of certain modes of 
contemporary pop music that while formally nostalgic are politically progressive nonetheless. Fisher is particularly drawn to the "overwhelming melancholy" of those versions of electronic music deploying analogue technologies often associated with the aptly named Ghost Box record label. That he regards the "hauntology" of these forms of electronica as progressive hinges on a very specific understanding of the term "spectre." As Derrida $(1994,2)$ notes, the most famous appearance of the noun comes in the opening line of the Communist Manifesto: "A spectre is haunting Europe - the spectre of Communism." The use of the term here reminds us that the spectral is not merely retrospective but prospective as well. The figure of the spectre is a disembodied manifestation of that which has passed but also that which has yet to come to pass. In the words of Martin Hägglund, it is at one and the same time both the "no longer" and the "not yet" (Fisher 2014, 18).

It is in part the multi-temporal nature of the spectral that informs Fisher's celebration of the "hauntology" of certain versions of contemporary electronica. In their use of analogue technologies from a bygone age, artists such as The Advisory Circle, Burial, and The Caretaker are seeking, Fisher (Ibid., 22-5) insists, to summon not merely the spectres of the past but also those of the future. Their intention, in other words, is not simply to return to some previous sepia-toned era bur rather to reclaim and reanimate the political dreams of "popular modernism" that germinated in those years before the neoliberal revolution. The melancholia that informs the artists that orbit around the Ghost Box label articulates, then, not an unwillingness to relinquish the past but rather a refusal to abandon the "lost futures" that once dwelled there. The "hauntology" of these cultural forms may well represent a form of nostalgia but it is, in the words of the late Pete Shelley, a "nostalgia for an age yet to come."

The ideas that Mark Fisher developed in his writings on "hauntology" provide a valuable - if, perhaps, at first glance unlikely - conceptual framework through which to examine certain television dramas based in Northern Ireland that have appeared in recent years. In these programs, we are reminded that the region remains haunted by the spectres of a conflict that has never quite been put to rest. They also underscore that there exists within Northern Irish society a certain sense of nostalgia, not only for the past but also for the future, or at least for a future that once seemed possible but was lost somewhere along the way. In the discussion that follows we will explore these themes through two recent popular television programs set in Northern Ireland that managed to reach a popular audience beyond the six counties but which otherwise could scarcely be more different.

\section{“All That My Jesus Is Better Than Your Jesus Stuff”}

When first aired on BBC2 in the spring of 2013, The Fall was an immediate hit with viewers, its blend of "noir" and "gothic" genres (Barton 2021, 36, 37) drawing the largest audiences the channel had enjoyed for almost a decade (Magennis 2016, 217). Set principally in Belfast, the program offers a depiction of the urban landscape that while "fresh" for the Northern Irish capital remains, as Charlotte Brunsdon $(2018,14)$ notes, "generically familiar for the television city: a place where women get 
murdered." The series opens as we watch Detective Superintendent Stella Gibson clean her bathroom and remove a cosmetic face mask before retiring to bed to read up on a murder case which, among others, will consume her energies for months to come. The following morning she is to fly to Belfast to conduct a twenty-eight day review on the investigation into the death of a young female architect. While DSI Gibson has no idea yet who is responsible for the murder, the audience has already been introduced to the killer of Alice Monroe. The opening scenes of the series that cast us as voyeurs observing the police officer conducting mundane domestic chores are intercut with ones depicting the killer, Paul Spector, engaged in his own act of covert surveillance outside the home of his next victim. As with all his previous targets, Sarah Kay is a dark-haired professional woman in her early thirties (Magennis 2016, 244).

As so often in fictional representations of serial killers, Paul Spector appears, at first glance, to be entirely "ordinary" (Barton 2021, 33, 34). A seemingly mild-mannered grief counsellor, he is also married with two young children and clearly especially besotted with his daughter Olivia. While that profile might well have shielded Spector from suspicion, an uncharacteristic moment of impetuousness will soon bring him to the attention of the authorities. The next murder that the serial killer has plotted fails to go to plan when the intended victim, Annie Brawley, returns home not alone, as expected, but in the company of her brother. Rather than flee, Spector decides to proceed as planned and in the ensuing struggle stabs the man to death with a pair of decorating shears later discarded by the killer as he hastens from the crime scene. An extensive search sees the police retrieve the murder weapon and the forensic evidence reveals the prime suspect to be Paul Spector. Once in custody, the true identity of the murderer gradually begins to reveal itself. The harrowing back story that unfolds provides some explanation of the birth of a serial killer and in the process dredges up some of the traumas that continue to haunt the society that spawned him.

One of the dilemmas facing the makers of The Fall was how to deal with the very specific context in which this rather more universal story is set. As Hill $(2006,191)$ has noted, there has been a propensity in contemporary television dramas set in Belfast to erase the troubled recent past of the city. In these programs, the Northern Irish capital is often depicted as a giddy site of conspicuous consumption by a young, cosmopolitan population that could be living in pretty much any urban outpost of late capitalism (Brown 2010). Belfast comes to be marked by a certain "placelessness" which suggests that it could in fact be "anywhere but Northern Ireland" (McLoone 2008, 58). In certain respects, the writers of The Fall have followed this recent trend of depicting the city as almost "placeless, abstract" (Steenberg 2017, 67). Many of the scenes in the series showcase the glossy, accelerated consumerism that is the hallmark of the "new Belfast" (Moore 2016). The opening episode, for example, shows the young lawyer Sarah Kay drinking with work colleagues in a chic downtown bar. Others are set in the various glamorous locations that animate the night-time economy of a Belfast that not so long ago closed down more or less completely in the early evening (Baker 2020). We see Spector meet his bogus love interest, schoolgirl Katie Benedetto, in an elegant restaurant in the recently minted "cathedral quarter," while DSI Gibson attempts, 
unsuccessfully, to seduce the pathologist Reed Smith in the fashionable local landmark Bert's Jazz Bar. The program also showcases the host of new hotels that have sprung up lately in a city once famous for the bombing of such enterprises. DSI Gibson has a night of passion with the soon-to-be-deceased police officer James Olson on her arrival in the Belfast Hilton, a structure that stands within metres of where the charred remains of the victims of the 1972 Bloody Friday bombings were shovelled into body bags. Later, she seems to have relocated to The Merchant-an exclusive hotel in what was once an almost derelict part of central Belfast - which has become ubiquitous in recent advertisements promoting the city.

The three seasons of The Fall feature, then, ample representations of the sites of breathless consumption that define the widely celebrated "new Belfast." Indeed, at times the program comes close to resembling a tourist advertisement, with Stephen Baker (ibid., 18) noting that, in spite of its "dark subject matter," official agencies for a time directed potential visitors to the city to the series' website which featured an interactive map of the various locations where filming took place. The frequent, seemingly positive representations of contemporary Belfast that appear in The Fall sit sideby-side, however, with others that recall the profoundly troubled recent past of the city (Steenberg 2017, 60). On her arrival, DSI Gibson is met by Assistant Chief Constable Jim Burns, a former romantic interest who takes the opportunity to warn her that policing is "different" in Northern Ireland, more "political." Gibson responds with characteristic hauteur, dismissing these claims to the specificity of the region as "all that my Jesus is better than your Jesus stuff." The very particular challenges and dangers of policing in Northern Ireland will, however, soon become very apparent. On her way to the police station that will house her investigation, Gibson is chauffeured past many of the landmarks and scars of the Troubles, taken on a journey past the now abandoned court house on the Crumlin Road and the principal, imposing peace line in west Belfast which anyone familiar with the geography of the city would know is neither a logical sequence of travel nor the shortest route to her destination. Arriving, eventually, at the barracks, she is greeted immediately by a photo montage of police officers killed in the Troubles, captioned with the phrase "our murdered colleagues" (Magennis 2016, 219).

It soon becomes apparent that such moments of political violence have not been consigned entirely to the past. In the second episode of the opening season, we see Constable James Olson, fresh from his extramarital tryst with DSI Gibson, return home only to be shot in the street, the killing witnessed by his young son looking on from his bedroom window. The gunmen are suspected to be dissident republicans, associates of two men Olson was in the process of prosecuting for another recent murder. A further threat of violence comes from loyalist paramilitaries still operating two decades after they declared a ceasefire. In a counselling session to address the loss of their son, Paul Spector asks the former loyalist prisoner Jimmy Tyler and his wife how things are "in the bedroom." Once the discussion has concluded, an enraged Tyler pursues Spector into a lift where he informs him that he has done "bad things" and tells him never to enquire about the couple's sex life again. Suspicious that the grief counsellor may be having an affair with his wife, the not-so-former paramilitary begins a campaign of intimidation that culminates with him shooting Spector while the latter is 
in police custody. At the hospital to which Spector is taken it transpires he is not the only person to arrive with a gunshot wound, leading one of the doctors to make the wryly amusing, but telling, enquiry: "What is this, the Seventies?"

Among the many victims of the "dark and troubled history" (Magennis 2016, 219) sketched in The Fall is, perhaps, the serial killer at the heart of the drama. As the series unfolds, we discover that Paul Spector is in fact the assumed name of someone who was once Peter Baldwin. His birth certificate reveals Baldwin to have been the outcome of a romance between a touring British soldier and a local Catholic woman. In nationalist districts such relationships were anathema, often leading to women being ostracized and publicly humiliated through "tarring and feathering" (Feldman 2003). It was perhaps a blessing in disguise then that the amorous squaddie disappeared before his son was born. The place of the soldier was later taken by another man but he also left while Baldwin was still a young child. On the day of his eighth birthday, Baldwin was informed by his mother that the person he had always considered his biological father was not actually so. Ten days later, he arrived home to find that his mother had hung herself from the back of her bedroom door. Now effectively an orphan, Baldwin would be shunted between a sequence of care homes on both sides of the Irish border. In one of these, he and the other residents were subjected to repeated sexual abuse at the hands of those responsible for their wellbeing. Deemed to be "a very pretty boy" by the paedophile priest in charge of the home, Baldwin would spend an entire year as his primary carnal prey (Magennis 2016, 230).

The predation to which the child who would become Paul Spector was subjected took place of course in the context of the widespread political violence of the Troubles and that association was not simply coincidental. Perhaps the most notorious site of sexual abuse of children in care in Northern Ireland was the Kincora Boys' Home in east Belfast. The paedophiles who preyed on youngsters living there included a number of loyalist paramilitaries, some of whom were agents working for British military intelligence. While the abuse happening at Kincora was widely known both by unionist politicians and covert state operatives, none of those with influence intervened to stop it. Indeed, the latter had a vested interest in the predation continuing, generating as it did the sorts of incriminating evidence that military intelligence officers often consider essential to their trade. There was, therefore, a chain directly connecting the violence against children taking place behind the doors of residential care homes and that happening on the streets outside. Over time, it would become apparent that the abuse happening in Kincora was far from isolated (Ibid., 229). In the summer of 2017, an official inquiry issued its harrowing report mapping out a network of residential homes in Northern Ireland in which children had been subject to sexual and other violence going back many decades (Historical Abuse Inquiry Report 2017).

That the figure of Paul Spector was one of the many victims of institutional violence provides some clues perhaps as to why he would later become a serial killer. It may well have been the agonies that he experienced as a child that prompted him to visit similar sexual violence on others as an adult. The writers of The Fall certainly 
seem to be interested in this familiar trope ${ }^{6}$ (Steenberg 2017, 65) at several points in the series' narrative arc. On the evening when ACC Burns arrives unannounced and with amorous intent at the hotel door of DSI Gibson, he recounts that he was the officer who arrested the paedophile priest who ran the home in which Spector spent part of his childhood. Seeking to draw a connection between the abuse that Spector experienced and his subsequent career as a serial killer, Burns speculates that "maybe this murderous fuck is a victim too."

The speculation that Spector somehow represents an apparition from Northern Ireland's violent past is an interesting notion that the script writers of The Fall flirt with occasionally but never quite seem able to commit to fully. The problematic manner in which this conjecture is handled becomes most starkly apparent in a key scene in the second season where the team of investigating officers are discussing the prime suspect's birth certificate. When it is revealed that Spector was born on 25 May 1979, ACC Burns reacts as if he has seen a ghost. The perennially harried senior policeman appends this disclosure with comments seemingly couched as explanation: "The year the Shankill Butchers were sentenced to life imprisonment for 19 murders, the year of Warrenpoint ${ }^{7}$. . .Bad year." The inference that these observations invite would seem to be that somehow Spector was preordained to become a monster by the timing of his birth, a "bad seed" cast to the winds by the violence that drew to a close the most troubled decade in Northern Ireland's most troubled history. The sheer absurdity of the thesis that ACC Burns seems to have just propounded is registered on the face of the unrequited love interest seated across the conference room. Not for the first time in the series, DSI Gibson fixes her superior officer with a look that expresses both contempt and concern that he may well have taken leave of his senses. In hindsight, the scene in which the "bad year" monologue appears in series two is one of those that heralds the rapid decline of a series that had begun with considerable promise. The inability of the script writers to decide what to do with the plot line about Spector's background as an abused child would prove emblematic of a broader, spiralling narrative incoherence ${ }^{8}$ that would see the third and final season aired in 2016 rendered largely incomprehensible (Barton 2021, 33).

For all its ultimate shortcomings, The Fall illustrates well the haunted tone of some recent representations of Northern Ireland on television. After all, the serial killer at the heart of the drama is - to mark, just once, the excruciating pun of his adopted surname (Magennis 2016, 220; Steenberg 2017, 65) - a spectre from the region's troubled recent history. The Fall invites us to remember the suffering of those children scarred by the experience of growing up in residential care in Northern Ireland. The program also suggests that these systematic patterns of abuse were facilitated and encouraged by the more overt, widespread forms of violence happening outside such baleful institutions. Finally, the writers of The Fall issue a critical reminder that attacks on women-largely overlooked during a conflict that saw so many (Magennis 2016, 231) —remain the single most substantial category of violence in the region. While the series often sets out to capture the glossy surfaces of the "new Belfast," there appear at the edge of its frames then the ghosts of Northern Ireland's violent past, and, indeed, its violent present. 


\section{"I'm Not Enjoying This Bomb"}

A rather gentler evocation of the dark days of the Troubles comes in the guise of Derry Girls. Scripted by Lisa McGee, a native of the city, the show has become an unlikely success with viewers in Britain and Ireland - and, indeed, elsewhere-since it was broadcast first in early 2018, drawing regular audiences of 2.5 million to make it the most popular program on Channel Four in recent years (Murphy and Aguiar 2019, 52). The series follows the adventures of four mid-adolescent Catholic girls from Derry"or Londonderry, depending on your persuasion" (Ganatra 2018) — who are joined by a male relative from across the Irish Sea ("the wee English fella") who is sent to their single-sex school for his own protection. Set in the mid-1990s, Derry Girls marks the key moments in the early stages of the Northern Ireland peace process, the time lovingly curated in period detail and the chart hits of the day. The success of the series hinges largely on its use of a local sense of humor that is rather lighter than the pitchblack version favored in Belfast and calls to mind, a little too deliberately perhaps at times, the whimsical tone of another hit Channel Four comedy, Father Ted.

While the mood of the series is mainly light-hearted, it has, at times, a real satirical edge. One episode pokes fun at the well-intentioned folly of cross-community schemes, when an attempt to create an ecumenical dialogue between the girls' school and a local Protestant boys' equivalent at an outdoor pursuits center descends into chaos. Prompted by an "ice-breaking" exercise to list on a blackboard that which divides and unites them, the pupils gleefully fill the "differences" column while the "similarities" one remains glaringly empty. The exercise deteriorates from that point on and ends with the ordinarily amiable Clare claiming that the Protestant boy feeding her rope as she abseils is attempting to kill her, leading her to yell to her friends below a request that may have required some explanation for viewers outside Northern Ireland: "don't let the Jaffa bastard hurt me!"' Another episode satirizes the Home Office Order introduced in 1988 which meant that interviews with political figures deemed to be "terrorists" or their fellow travellers could be broadcast only if their voices were dubbed by actors who often sounded uncannily like them. Watching Gerry Adams being ventriloquized thus on local television, the fantastically self-absorbed Aunt Sarah muses that the authorities will not allow the republican's own voice to be heard because a British audience would simply find it too seductive. The distinctive timbre of the then Sinn Féin President, she insists, makes him sound like a "west Belfast Bond." Perhaps the darkest moment of political satire to appear in Derry Girls comes in the pilot episode in which the sweet-natured Clare is observing a twenty-four hour fast to raise funds to help an Ethiopian child. The other girls seem entirely uninterested in this undertaking, with Erin in particular rather more concerned with persuading someone to accompany her to a gig that evening organized by an older boy on whom she has her eye. Exasperated by Erin's constant pleading, the sharp-tongued Michelle gestures toward the increasingly famished Clare, before suggesting: "bring Bobby Sands." It is perhaps a testimony to the good will that the show has generated that this passing, mischievous reference to the dead republican hunger striker never even seemed likely to become a matter of public controversy. 
The armed conflict that provides the backdrop to Derry Girls is mainly observed with a certain wry detachment. In the show's pilot episode, the extended family of the principal character Erin are gathered around the television on the first morning of the new school year watching the news about a bomb scare that has closed one of the bridges across the Foyle river that divides the city in both geographical and sectarian terms. While for many people elsewhere this would be the source of some anxiety, the Quinn family seem to regard it as somewhere between a minor annoyance and an amusing distraction. There is speculation from several quarters that the girls will be late for school as they will be required to take the "long way round." The response of Aunt Sarah is, inevitably, rather more solipsistic. In her trademark deadpan drawl, she expresses some concern that she may not make a midday appointment at a tanning salon on the other side of the river, moving her to issue the classic line: "Well, I don't know about the rest of ya, but I'm not enjoying this bomb."

The various protagonists in the conflict that feature from time to time in Derry Girls, moreover, rarely appear to be especially menacing. In the episode where the girls and their families attempt to leave the city and head for Donegal in a vain effort to avoid the Orange parades, it transpires that an IRA man has stowed himself away in the boot of one of their cars. As the discussion whether to allow him to remain there while they cross the border takes various twists, the paramilitary Emmett watches on with a bemused equanimity that was scarcely the trademark of republican combatants while the Troubles raged. Furthermore, while British soldiers are routinely depicted patrolling the walled city of Derry, the girls at the center of the drama barely seem to notice them any longer. On one occasion, the school bus is stopped at a checkpoint and army personnel get on to conduct a search. To the astonishment of the recently-arrived James, the girls scarcely register the presence of the soldiers until his cousin, the sexually precocious Michelle, notes the transgressive appeal of finding a squaddie attractive and gestures toward one of them while asking her friends: "Do you think if I told him I'd an incendiary device down my knickers, he'd have a look?"

Although not alone of course in its attempts to play Northern Ireland's abiding political tensions for laughs, what sets Derry Girls apart from other recent television series is another, often overlooked, quality of the sitcom. The program is best known for its gentle, idiosyncratic comedy but perhaps its greatest attribute is a facility for occasional moments of "great poignancy" (McKay 2019). The pathos that punctuates Derry Girls is best illustrated perhaps in the episode that closes the first season. Here we see the adults in the Quinn family gathered once more around the television to hear a local broadcaster announce yet another atrocity. The news that twelve people are dead reduces all of them to stunned silence, the shock even sufficient to persuade Granda Joe to call a momentary halt to his incessant haranguing of son-inlaw Gerry for being from the "Free State." As they look on in mute disbelief, the patriarch approaches the southern Irish man and gently places an empathetic hand on his shoulder.

The poignancy of that memorable scene is heightened even further by its juxtaposition with another that could scarcely be more different (McIntyre 2021). In a moment of folly, Erin's cousin Orla has decided to enter the school talent contest to exhibit her 
step aerobics skills. As the derision of the audience becomes increasingly audible, her friends take to the stage and begin copying her routine as an act of solidarity. In the closing moments of the opening season, we are taken back and forth between the titular characters dancing euphorically at the school talent show and their elders devastated by the news of yet more pointless bloodshed. Those intercutting images disclose quite explicitly the counterpoint at the center of the series, namely the disjunction between the experience of an older generation forced to live through the Troubles and the expectation of their (grand)children that their own lives might be rather better. That the final image of the debut season is that of the girls whirling one another around on the school stage underscores perhaps that their hopes for the future might just be realized.

That mood of optimism would be captured more explicitly in the penultimate episode of the second season. Once again, we meet the Quinn adults circling the television, which on this occasion has stopped working. After a sequence of not terribly technical procedures, Gerry manages finally to coax the screen back into life just as the newscaster announces that the IRA have called a ceasefire beginning at midnight. The welcome news brings the Quinns out onto the street to celebrate with their neighbors. It would be hard not to be moved by the evocation here of that glorious, sunkissed day in the late summer of 1994 when it seemed, finally, that the Troubles might just be over.

At the heart of Derry Girls is a poignant depiction of a specific time and place drawn largely from the autobiographical details of its writer. The pathos that is such a neglected attribute of the series evokes not merely a particular passage in Northern Ireland's recent history but also the rich possibilities that seemed to exist at that moment. What Derry Girls captures well at times is the tentative mood of optimism that was kindled as the peace process gained momentum during the 1990s (Ferguson 2018). That sense of possibility has of course been challenged and largely dissipated during the quarter century that has elapsed since. In the episodes of Derry Girls, our minds are called back to a time when there seemed the possibility of a genuinely progressive future for Northern Ireland, one very far removed from the sectarian squabbling that would come to define the era of restored devolved government. The spectres that the program conjures up then are not only those of a "lost past" but also those of what often seems to be a "lost future." Or, to return to the vocabulary introduced earlier, what the occasionally genuine pathos of the series manages to summon is not just the "no longer" of Northern Irish society but the "not yet" as well.

While the gentle longing for a previous version of Northern Ireland - and its still latent possibilities - that we find in Derry Girls appears entirely innocent, it is worth remembering that it may well have an evil twin. As Glenn Patterson $(2019,102-4)$ has noted, there seems to exist a certain "Troubles nostalgia" even among some people fortunate enough not to remember that baleful period. One of those intent on staging a simulacrum of the Northern Irish conflict may well have been responsible for a tragic event that occurred within sight of the city walls that provide a dramatic backdrop for several scenes in Derry Girls. In April 2019, the final episode of the hugely successful second season of the program aired on Channel Four. Later the same month, the 
emerging author and journalist Lyra McKee was killed by a stray round discharged as she watched rioting orchestrated by dissident republicans in the Creggan district of the city (McIntyre 2021). McKee had written about the plight of the "ceasefire babies" who had come of age after the conflict but were yet to reap the benefits of the peace process (Murphy and Aguiar 2019). It may well have been another member of that same cohort who was responsible for her death. While there has yet to be a prosecution arising from the murder, the prime suspect seems to be a male who was only eighteen at the time of the incident (Barnes 2019). The tragic early death of Lyra McKee provides an important reminder that nostalgia can at times assume a poisonous form, that those who are unwilling to "give up the ghost" of a conflict that should really have been over a long time ago are capable of creating yet more spectres to haunt Northern Ireland.

\section{Conclusion}

There are, therefore, certain works of television fiction broadcast in the last decade that cast light on what Declan Long $(2017$, x) has called the "disconcerting, backwards-and-forwards realities" of contemporary Northern Irish society. In so many respects, Northern Ireland has left its violent past behind and at times seems almost indistinguishable from other outposts of late capitalism. In so many others, however, the region seems unable to come to terms with the traumas associated with all those people who were lost during the Troubles and all those possibilities that were lost after the conflict drew finally to a close. The quintessentially dialectical, almost bipolar, nature of contemporary Northern Irish society is captured well in the pair of dramatically different television series discussed above. While The Fall showcases the heady consumption of the much-vaunted "new Belfast," it also reveals the spectres that still exist amid all the gloss of the reanimated city. And although Derry Girls documents the mood of guarded optimism that accompanied the early stages of the peace process, the series conveys simultaneously those feelings of loss that the seemingly progressive possibilities latent in those moments would never be realized. For all their obvious differences of tone and subject matter, what both these recent television series provide us with is, therefore, a sense of the "hauntology" of a society that even now seems not quite able to learn to live with its many ghosts.

\section{Acknowledgments}

I would like to thank Carmen Kuhling, William Marcus, Gavan Titley and the two anonymous reviewers for their helpful comments on previous versions of this article.

\section{Declaration of Conflicting Interests}

The author declared no potential conflicts of interest with respect to the research, authorship, and/or publication of this article. 


\section{Funding}

The author received no financial support for the research, authorship, and/or publication of this article.

\section{Notes}

1. The quotes here are from the text officially entitled Agreement reached in the multi-party talks (1998).

2. The cultural realm in which the spectres and legacies of Northern Ireland's traumatic recent past are explored most explicitly is, arguably, that of contemporary literature. To take two of the most celebrated examples, the Troubles provides the backdrop for Anna Burns' claustrophobic Booker Prize winner Milkman (2018), while Jan Carson's acclaimed magic realist novel The Firestarters (2019) captures the nostalgic appeal of the conflict for those fortunate enough not to have lived through it.

3. The movies alluded to here are, respectively: An Everlasting Piece (Barry Levinson, 2000), With or Without You (Michael Winterbottom, 1999), and Wild About Harry (Declan Lowney, 2000).

4. While the newfound popularity of the region as a film location for both cinema and television is often attributed to its versatility as the "biggest set in the world," it should perhaps be attributed primarily to the generous tax incentives introduced to lure the culture industries to Northern Ireland (Ramsey et al. 2019).

5. The lyric appears on the track "Nostalgia" from the second Buzzcocks album Love Bites (United Artists, 1978).

6. References to incidents of child sexual abuse and their connections to other forms of violence are especially abundant in contemporary Irish television and cinema. In his analysis of The Butcher Boy (1997), for instance, Martin McLoone (2000) frames the central character, prepubescent killer Francie Brady, using singer Sinead O'Connor's notion of Ireland as "the abused child of history." Moreover, in their reading of the television adaptation of Eureka Street (1999), McLaughlin and Baker (2010) suggest that the "ebullient urchin" Roche, last seen in hospital recovering from a paramilitary punishment beating, might be seen as a metaphor capturing the neglect and uncertainty of wider Northern Irish society (p. 82).

7. In August 1979, Provisional IRA bombs killed 18 British soldiers at Warrenpoint, the worst casualties suffered by state forces during the conflict.

8. A case in point pertains to the ethnoreligious affiliation of the male lead. While the background of his mother and the residential homes to which he was assigned suggest Paul Spector to be Catholic, that designation is disrupted at certain moments in the series. In the opening season, for instance, he is called a "Jew boy" by loyalist Jimmy Tyler (Barton 2021, 42), while in the second his wife responds to his plea that she not terminate her pregnancy by enquiring: "Why not? We're not Catholic." Spector then replies that his mother, though, was a Catholic, a comment that does not appear to come as a surprise to his spouse and which is simply left hanging. While this complicated ethnoreligious biography may well originally have been an attempt to create another layer of mystery around the serial killer, the result was merely to sow further confusion among the program's dwindling audience.

9. The "Jaffa" is a variety of orange, the color closely associated with the marching traditions of Northern Irish Protestants. The term is hence used as slang to designate someone from the unionist community. 


\section{References}

Abraham, Nicholas, and Maria Torok. 1978. L'Écorce et le noyau (The Shell and the Kernel). Paris: Flammarion.

Baker, Stephen. 2020. "Tribeca Belfast and the On-Screen Regeneration of Northern Ireland." International Journal of Media and Cultural Politics 16 (1): 11-26.

Barnes, Ciaran. 2019. "Lyra McKee Murder Suspect Set to be A Dad - Teen's Baby Conceived Same Week of Fatal Shooting." Belfast Telegraph, August 12.

Barton, Ruth. 2019. Irish Cinema in the Twenty-First Century. Manchester: Manchester University Press.

Barton, Ruth. 2021. "Trauma, Motive and the Post-Troubles Psychopath in The Fall." Television \& New Media 22 (1): 32-46.

Brown, Matthew. (2010) "Cities Under Watch: Urban Northern Ireland in Film." Éire-Ireland 45 (1\&2): $56-88$.

Brunsdon, Charlotte. 2018. Television Cities: Paris, London, Baltimore. Durham, NC: Duke University Press.

Coulter, Colin, and Peter Shirlow. 2019. "From the 'Long War' to the 'Long Peace': An Introduction to the Special Edition." Capital \& Class 43 (1): 3-21.

Derrida, Jacques. 1994. Specters of Marx: The State of the Debt, the Work of Mourning and the New International. Abingdon: Routledge.

Feldman, Allen. 2003. "Political Terror and the Technologies of Memory: Excuse, Sacrifice, Commodification, and Actuarial Moralities." Radical History Review 85: 58-73.

Ferguson, Frank. 2018. "Home to a Ghost: Ulster-Scots Language and Vernacular in Northern Irish Culture Since the Good Friday Agreement." Przeglad Kulturoznawczy 3 (37): 335347.

Fisher, Mark. 2014. Ghosts of My Life: Writings on Depression, Hauntology and Lost Futures. Alresford: Zero Books.

Graham, Colin. 2005. “'Every Passer-by a Culprit?' Archive Fever, Photography and the Peace in Belfast. Third Text 19 (5): 567-580.

Ganatra, Shilpa. 2018. "How Derry Girls Became An Instant Sitcom Classic." The Guardian, February 13.

Hill, John. 2006. Cinema and Northern Ireland: Film, Culture and Politics. London: British Film Institute.

Historical Abuse Inquiry Report. 2017. Belfast: Historical Institutional Abuse Inquiry. https:// www.hiainquiry.org/

Long, Declan. 2017. Ghost-Haunted Land: Contemporary Art and Post-Troubles Northern Ireland. Manchester: Manchester University Press.

Magennis, Caroline. 2016. “'That's Not so Comfortable for You, is it?' The Spectre of Misogyny in The Fall. In The Body in Pain in Irish Literature and Culture, edited by Fionnuala Dillane, Naomi McAreavey, and Emilie Pine, 217-234. London: Palgrave Macmillan.

McIntyre, Anthony. 2021. Transnationalism, Diaspora and Regionality in 21st Century Irish Popular Culture. London: Palgrave Macmillan.

McKay, Susan. 2008. Bear in Mind These Dead. London: Faber and Faber.

McKay, Susan. 2019. "The Fabulous, Feral Derry Girls are the New Emblems of Northern Ireland. The Guardian, March 6.

McLaughlin, Greg, and Stephen Baker. 2010. The Propaganda of Peace: The Role of Media and Culture in the Northern Ireland Peace Process. Bristol: Intellect Books. 
McLoone, Martin. 2000. Irish Film: The Emergence of a Contemporary Cinema. London: British Film Institute.

McLoone, Martin. 2008. Film, Media and Popular Culture in Ireland: Cityscapes, Landscapes, Soundscapes. Dublin: Irish Academic Press.

Moore, Robert. 2016. "Rebranding Belfast: Chromatopes of Post-Conflict." Signs and Society 4 (S1): 138-162.

Murphy, Oonagh, and Laura Aguiar. 2019. "When a 1981 Diary Meets Twitter: Reclaiming a Teenage Girl's Ordinary Experience of the Northern Irish Troubles. British Journal for Military History 5 (1): 49-70.

Patterson, Glenn. 2019. Backstop Land. London: Head of Zeus.

Ramsey, Phil, Stephen Baker, and Robert Porter. 2019. "Screen Production on the 'Biggest Set in the World:' Northern Ireland Screen and the Case of Game of Thrones." Media, Culture \& Society, 41 (6): 845-862.

Steenberg, Lindsay. 2017. "The Fall and Television Noir." Television \& New Media 18 (1): $58-75$.

\section{Author Biography}

Colin Coulter is Professor of Sociology in the Department of Sociology, National University of Ireland, Maynooth. His most recent book is the edited collection Working for the Clampdown: The Clash, the Dawn of Neoliberalism and the Political Promise of Punk (Manchester University Press, 2019). 